\title{
Factors influencing the information quality of local government financial statement and financial accountability
}

\author{
Nur Fitri Dewi ${ }^{a^{*}}$, S. M. Ferdous Azam ${ }^{a}$ and Siti Khalidah Mohd Yusoff ${ }^{b}$
}

${ }^{a}$ Post Graduate Centre, Management and Science University, University Drive, Off Persiaran Olahraga, Section 13, 40100, Selangor, Malaysia

${ }^{b}$ Graduate School of Management, Management and Science University, University Drive, Off Persiaran Olahraga, Section 13, 40100, Selangor Malaysia

\section{CH R O N I C L E}

\section{Article history:}

Received: April 15, 2019

Received in revised format: April

272019

Accepted: May 14, 2019

Available online:

May 14, 2019

Keywords:

Internal control system

Human resource competence

Information quality of financial

statement

Financial accountability

\section{A B S T R A C T}

\begin{abstract}
The purpose of this paper is to study the effect of internal control system and human resource competence on information quality of local government financial statement and financial accountability. The method of collecting data is questionnaire which is distributed among 161 out of 303 population of employees of the Agency (Dinas) in the Government of South Sumatra Province, Indonesia. The collected data is processed by using SPSS 20.00 with t-test and Path Analysis. The result shows that internal control system and human resource competence positively influenced on the information quality of local government financial statement. Internal control system and human resource competence also influence positively on financial accountability both directly and indirectly mediated by the information quality of local government financial statement. Moreover, the information quality of local government financial statement directly and positively influence the financial accountability. The results of this study can be beneficial for the government as input and material considerations in determining policies specifically related to improve the quality of information on government financial statements and financial accountability.
\end{abstract}

(C) 2019 by the authors; licensee Growing Science, Canada

\section{Introduction}

The development and enhancing conscious of new public management reforms for over two decades is still continuing as government is looking for reformation and restructuring to enable better delivery of public services (Tarofder et al., 2017; Thomas \& Nadiyasu, 2017). The debate for good governance began in the late 1980s due to the introduction of New Public Management (NPM) in the UK and other developed countries in the world where NPM was first adopted and then resulted in a new adoption approach to public sector management reform (Grace, 2015). International Federation of Accountants stated that to build trust in the government, it is crucial that governments give accurate and complete information about expenditures and transactions, to show accountability and management, and to strengthen their own credibility (IFAC, 2012). The type of information needed can be presented through high-quality, strong and effective accrual-based financial reporting systems, which enable for government assets and liabilities to be recorded, reported and properly disclosed because they are monitored effectively (IFAC, 2012). According to the Index of 150 current jurisdictions in the world of 2018, 37 governments (25\% of jurisdictions covered by the Index) report accrual basic in published financial statements, while $45 \%$ 
switch to accruals or already have several accrual elements in their financial statements and $30 \%$ of the government still reports in cash basic (IFAC, 2018).

The development of the public sector in Indonesia is a strong demand for public accountability institutions, both central and regional level (Indriasih \& Koeswayo, 2014). The Minister of Administrative Reform and Bureaucratic Reform of Indonesia, Asman Abnur revealed that currently the majority of local governments still have sub-standard accountability values, namely under B throughout 2016 (Nurmayanti, 2017). The presentation of financial statements is one form of implementation of public financial management accountability (Iskandar \& Setiyawati, 2015). The financial statements should be in accordance with Government Regulation No. 24 (2005) updated by Government Regulation No. 71 (2010) on Government Accounting Standards (SAP) (Nurlis, 2018). One of the indicators of the quality of financial accountability is seen from the opinion of external auditors (BPK) on the presentation of government financial statements (Idris et al., 2018). The opinion of the Supreme Audit Agency (BPK) consistently consists of: Unfair (TW), Not Giving Opinion (TMP), Fair With Exception (WDP), and the best is Unqualified (WTP).

South Sumatra Province get WTP opinion 4 times in a row. However, there are still many irregularities found in South Sumatera indicating that the government of South Sumatera still has many weaknesses. As stated by Ir Isma Yatun MT as Member V of the Republic of Indonesia's Supreme Audit Board (BPK) in the Plenary Session of XV of the South Sumatra Provincial DPRD, the State Audit Board (BPK) still found several problems in preparing the Regional Government Financial Statements, including the findings of the examination concerning compliance with laws and regulations, where there is still a financial waste for the construction of environmental roads and the Province of South Sumatra which is not distributing profit sharing to the regions (Hafiz, 2017). This is contrary to the Reform Regulation Number 15 of 2004 which regulates the criteria for giving opinions on financial statements which is one indicator of the quality of financial statements. Based on the problems emerge in the field and the theory used, there are several factors that may affect the quality of financial reporting, such as: effectiveness of internal controls (Nurlis \& Yadiati, 2017) and human resource competence (Nurlis \& Yadiati, 2017). According to interviews conducted by the International Federation of Accountants (IFAC) with 25 key business leaders, summarized in Integrating Business Reporting Supply Chains, the recent financial crisis has exposed deformed or ineffective risk management and internal control performances, specifically in some financial institutions. Many organizations were too focused on financial reporting controls, and did not fully understand the risks they face. In fact, many, if not most, risks originating in other fields, including operations and external circumstances. Facts that occur in the field show that from the examination of Supreme Audit Agency (BPK) of 542 LKPD of Indonesia reported in Summary of Semester Examination Results (IHPS) I (2018) found 6.222 cases of weakness of Internal Control System (SPI) consisting of 2.083 problems of weakness of accounting and reporting control system, 2.887 problems of weaknesses of the control system of budget execution and expenditure execution, and 1.252 problems of internal control structure weakness (Audit Board of the Republic of Indonesia, 2018). In addition to internal control problems, BPK also finds the issue of non-compliance with the provisions of legislative regulations as many as 6.558 cases covering problems that have financial impacts and errors in administrative irregularities. Financial problems resulted in losses, potential losses and shortages of revenues worth Rp 2.54 trillion (Audit Board of the Republic of Indonesia, 2018). Achieving goals in an organization depends mainly on employees (Perera et al., 2013). Future benefit and supportability of present day organizations rely on intellectual capital of the organization and its capacity to co-make with employees (Apekshanirmali et al., 2017). When the right employee has been chosen, the manager must do important role to lead employee behavior that affects high employee performance in the organization (Albattat, 2018). This will help in improving the capabilities and competencies of human resources. Having in place a high-performing leadership team, a thinking organization and managers and employees at all levels passionately committed to accomplish tasks (Rahman et al., 2018). Employees need the right qualifications and good competencies in order to work optimally. Employee competency also influences the making of good financial statements that describe how well the achievement of an organization. 
Qualified human resource can enhance the information quality on financial statement (Nurlis \& Yadiati, 2017). Vice President Boediono (2011) in Kasim (2015) said that based on reports obtained, the lack of qualified human resources with the ability to make high quality financial statements is the main reason to the poor financial statement quality in government institution.

Based on the phenomenon related to the weaknesses of internal control systems that occur and the pros and cons of the influence of human resources on the quality of government financial Statement information that affect the achievement of financial accountability, the researchers are interested in examining the factors influencing the information quality of local government's financial statement and financial accountability. Because this research emphasizes on internal control systems and human resource competencies as indicators, the results will show which indicators are higher than others, so that the government can improve other indicators to reduce problems in the preparation of financial statements to improve the quality of financial reporting information and accountability finance in government. Furthermore, this research is expected to contribute ideas to the government of South Sumatra Province to maximize the existing internal control system and the competence of its resources, so that it can truly produce quality information from financial statements and improve regional financial accountability.

\section{Literature Review}

Basically public sector organizations are built on agency theory. Recognized or not in government there are relationships with agency problems (Halim \& Abdullah, 2006). In agency theory, Jensen and Meckling (1976) and Sieger et al. (2013) define agency relationship as a contract in which one or more principals hire agents to perform some services for their benefit by delegating some powers of decision making to agents. Based on the agency theory, the practice of financial reporting in public sector organizations is a concept based on agency theory. In financial reporting, the government acting as agent has the obligation to provide useful information to users of government financial information acting as principal in assessing accountability and making decisions whether economic, social and political decisions and either directly or indirectly through its representatives (Nur, 2015). In addition to agency theory, another theory underlying this research is Stakeholder theory. The term Stakeholder was first introduced by the Stanford Research Institute (RSI) in 1963 by Freeman (1999). Freeman Matuleviciene \& Stravinskiene (2015) defines stakeholders as groups or individuals that can influence or be influenced by the process of achieving organizational goals. Abi et al., (2018) explain stakeholder theory as a theory which states that all stakeholders have the privilege to get information about the activities of the company that can impact their decision-making. Anggriawan and Yudianto (2018) believe that local governments are responsible for publishing financial statements to stakeholders. Xu et al. (2003) in Anggriawan \& Yudianto (2018) state that information will be useful if the information can support decision making and can be understood by the users. Therefore, the government must ensure the quality of local financial statement information so that the financial statements are beneficial for stakeholders.

\subsection{Financial Statement}

The financial statements are records of financial information of a company in an accounting period that can be used to describe the performance of the company (Wikipedia, 2018). According to Fung (2014), without the required data and information, it is difficult to completely comprehend the financial condition. The financial statements to be prepared by the government as stipulated in Government Regulation Number 71 of 2010 on Government Accounting Standards include: Budget Realization Report (LRA), Balance Changes of Budget Report (SAL Change Report), Balance Sheet, Operational Report (LO), Report Cash Flow (LAK), Statement of Changes in Equity (LPE), and Notes to Financial Statements (CaLK).

\subsection{Information Quality}

English (1996) in Karagül and Özdemİr (2012) described information quality is reliably living up to 
clients' desires and through information and information services empowering them to play out their work successfully. Quality of financial reporting is complete and transparent information, designed not misleading to users (Jonas and Blanchet, 2000 in Sudiarianti et al., 2015). In the context of regional financial statements, financial statement information in this study is said to be qualified if it meets the qualitative characteristics of the financial statements contained in Government Regulation No. 71 of 2010. Qualitative characteristics of financial statements are normative measures that need to be realized in accounting information to meet its objectives. The following four characteristics are the normative prerequisites required for the government's financial statement to meet the desired quality, which are relevant, reliable, comparable and understandable.

\subsection{Financial Accountability}

One of the standards in the use of good administration is accountability (Ramdhani et al., 2016). Financial accountability is a form of accountability for public institutions to use public funds economically, efficiently and effectively, there is no waste and leakage of funds, as well as corruption (Zeyn, 2011). Further the Module of Socialization of Government Accountability Performance Accountability System (AKIP) said that an adequate form of accountability media is a form of report that can express the achievement of goals through the management of an organization's resources (Lembaga Administrasi Negara, 2000). Zeyn (2011) states that there are four dimensions of financial accountability that must be fulfilled by public sector organizations (legal entities); namely formulation of financial plans (budgeting process), implementation and financing of activities, evaluate financial performance and implementation of financial reporting.

\subsection{Internal Control System}

The excellence of the design of internal controls is extremely important to the accomplishment of an association (Bin Abdullah \& Nor Izah Ku Ismail, 2008). Internal control is a framework of arrangements and systems that give protection to a unit's assets and other different assets usable by the association, precise and dependable financial reporting confirmation, principles or laws and controls consistence advancement, and accomplishment of productive and successful tasks (Dzomira, 2014). In Indonesia, internal control system is set within Government Regulation No. 60 of 2008. According to Government Regulation No. 60 of 2008, the Government Internal Control System consists of several elements, namely control environment, risk assessment, control activates, information and communication and monitoring internal control.

\subsection{Human Resource Competence}

Human resources are viewed as one of the most significance of the present organizations (Isaiah \& Ericsson, 2012). Competence-based human resources can improve capacity and build foundations, because if the people working within the organization have the right competence in accordance with the demands of their work, these people are able both in terms of knowledge, skills, and mental and productive character (Hutapea and Thoha, 2008: 86). Spencer and Spencer (1994) in Hutapea and Thoha (2008) revealed that there are three main components of the formation of competence, which are knowledge, skills and behavior. In good local financial management, regional work unit (OPD) must have competence and qualified human resources, supported by accounting education background, often follow education and training, and have experience in finance (Sagara, 2015). Then to apply the accounting system, human resources (HR) quality will be able to understand the logic of accounting well.

\subsection{Research Model}

The hypotheses determined by t-test or partial significance test and path analysis. In path analysis, the model will have two equations, which can be described as follows,

$$
\begin{aligned}
& Y=p Y X_{1}+p Y X_{2}+e_{1}, \\
& Z=p Z X_{1}+p Z X_{2}+p Z Y+e_{2},
\end{aligned}
$$


where:

$$
\begin{array}{ll}
\mathrm{X}_{1}=\text { Internal Control System }, & \mathrm{Y}=\text { Information Quality of Local Government Financial Statement }, \\
\mathrm{X}_{2}=\text { Human Resource Competence }, & \mathrm{Z}=\text { Financial Accountability. }
\end{array}
$$

Furthermore, to complement the structural equation is to calculate path coefficients. The path coefficients can be calculated using the formula:

$$
e 1=\sqrt{1-R^{2}} \quad e 2=\sqrt{1-R^{2}}
$$

\subsection{Hypotheses}

The hypotheses proposed in this study are:

H1: Internal control system has positive effect on the information quality of local government financial statement.

H2: Human resource competence has positive effect on the information quality of local government financial statement.

H3: Internal control system has positive effect on the financial accountability.

H4: Human resource competence has positive effect on the financial accountability.

H5: Information quality of local government financial statement has positive effect on the financial accountability.

\section{Research Methodology}

The purpose of this research is to examine the influence of internal control system (independent variable) and human resource competence (independent variable) on the information quality of local government financial statement (intervening variable) and its impact on financial accountability (dependent variable) in South Sumatra, Indonesia. This research uses quantitative approach with primary data received from questionnaire. The questionnaire comprises of closed and constructed applying questions Likert scale. This study requested for data to be collected from 26 offices in South Sumatra, Indonesia. The data are analyzed by statistical procedures using SPSS 20.0.

\subsection{Sampling Technique}

Sample in this study are staff / employees performing accounting / finance functions at all agencies in South Sumatra, taking into consideration that accounting staff as well as the financial department of the agencies are parties directly involved in the process of recording financial transactions of the agencies and one part in charge to produce government financial statements. To determine the sample size in each Dinas the researchers used Isaac and Michael's formula, which is to determine the number of samples from a certain population for error rate of $1 \%, 5 \%$, and $10 \%$. From the table Isaac and Michael it is known that from the population of 303 respondents, the sample includes 161 respondents.

\subsection{Test of Validity and Reliability}

Reliability value of each variable is 0.804 for the internal control system variable, 0.795 for human resource competence variable, 0.776 for the information quality of local government financial statement and 0.788 for financial accountability. Variable of internal control system $\left(\mathrm{X}_{1}\right)$, human resource competence $\left(\mathrm{X}_{2}\right)$, information quality of local government financial statement $(\mathrm{Y})$ and financial accountability (Z) have correlation coefficient values above 0.30 . Hence, it can be concluded that all items in the four variables are valid. Thus the requirements for the validity of the measuring instrument are complied.

\section{Findings}

Findings of the study consists of the demographic information, classic assumption test, hypothesis test and path analysis. Demographic information will discuss about gender, age, degree of education, educa- 
tional background and length of work. Classical assumption test consists of normality test, multicollinearity test, and heteroscedasticity test. Hypothesis test and path analysis will discuss about the findings of data analysis.

\subsection{Demographic Information}

Based on the questionnaire result, it can be concluded that the majority of employees at the Agency (Dinas) in the Province of South Sumatra were female (87 or 54\%). The age of the respondents, where were mostly $40-50$ years old with the percentage of $41 \%$. The majority of respondent's educational level was undergraduate education level with a frequency of 72 representing $45 \%$ of the respondents. The educational background of the respondents are from Economic / Accounting totaled 65 people with a percentage of $40 \%$, followed by other majors (Engineering, Law, etc.) with a percentage of $34 \%$, and the smallest percentage is the Department of Public Administration, amounting to 25\%. While the majority of the group of length of work among the respondents are from $6-10$ years group with 73 people representing $45 \%$ of the respondents.

\subsection{Classical Assumption Test}

Based on the results of the normality test using the Kolmogorov Smirnov One Sample method it is known that both of Eq. (1) and Eq. (2) have the significance value (Asymp. Sig 2-tailed) more than 0.05, namely 0.097 and 0.105 . Then the residual value is normal and available data can be used in statistics. Multicollinearity tests of this study were by looking at Tolerance and VIF values. The Tolerance value of the Eq. (1) and Eq. (2) are more than 0.10 and the Variance Inflation Factor (VIF) value is less than 10 , and it can be concluded that there is no multicollinearity problem in the regression model of Eqs. (12). Moreover, heteroscedasticity test in this study used Glejser test. The regression model of Eq. (1) have maintained probability values greater than 0.05 , namely 0.064 and 0.546 . In addition, the model stated in Eq. (2) have maintained a significance values of more than 0.05 , namely $0.465,0.845$ and 0.305 , respectively. It can be said that there was no problem of heteroscedasticity in the regression model of Eqs. (1-2)

\subsection{Partial Significance Test (t-test)}

The $t$ test or partial test aims to test the hypotheses in this study, either in Eq. (1) or in Eq. (2). The test used a significance level of 0.05 . The value of $t$ table in Eq. (1) is $\mathrm{df}=158(\mathrm{df}=161-2-1)$ and the value of $t$ table in Eq. (2) is $\mathrm{df}=157(\mathrm{df}=161-3-1)$. The results of the $\mathrm{t}$ test can be seen in Table 1 as follws.

Table 1

\begin{tabular}{|c|c|c|c|c|c|c|c|}
\hline \multicolumn{2}{|r|}{ Model } & \multicolumn{2}{|c|}{$\begin{array}{l}\text { Unstandardized } \\
\text { Coefficients }\end{array}$} & \multirow{2}{*}{$\begin{array}{c}\text { Standardized } \\
\text { Coefficients } \\
\text { Beta } \\
\end{array}$} & \multirow[t]{2}{*}{$\mathrm{t}$} & \multirow[t]{2}{*}{ Sig. } & \multirow[t]{2}{*}{ t-count } \\
\hline & & $\mathrm{B}$ & Std. Error & & & & \\
\hline \multirow{3}{*}{1} & (Constant) & 18.691 & 3.382 & & 5.526 & .000 & \\
\hline & Internal Control System & .222 & .036 & .422 & 6.185 & .000 & 1.65455 \\
\hline & Human Resource Competence & .328 & .064 & .347 & 5.089 & .000 & 1.65455 \\
\hline
\end{tabular}

a. Dependent Variable: Information Quality of Local Government Financial Statement

Table 1 shows the influence of the internal control system, human resource competence on information quality of local government financial statements partially. While the results of the t-test in Eq. (2) can be seen in Table 2. Table 2 shows the results of the test given in Eq. (2) where it shows the influence of the internal control system, human resource competence and information quality of local government financial statements on financial accountability partially. The criteria for decision making are:

a. If $\mathrm{t} \leq \mathrm{t}$ table then Ho is accepted and Ha is rejected.

b. If $t$ count $\geq t$ table then Ho is rejected and Ha is accepted. 
Table 2

Partial Significance Test (t-test) Result of Eq. (2)

\begin{tabular}{|c|c|c|c|c|c|c|c|}
\hline \multirow{2}{*}{\multicolumn{2}{|c|}{ Model }} & \multicolumn{2}{|c|}{$\begin{array}{l}\text { Unstandardized } \\
\text { Coefficients }\end{array}$} & \multirow{2}{*}{$\begin{array}{c}\begin{array}{c}\text { Standardized } \\
\text { Coefficients }\end{array} \\
\text { Beta } \\
\end{array}$} & \multirow[t]{2}{*}{$\mathrm{t}$} & \multirow[t]{2}{*}{ Sig. } & \multirow[t]{2}{*}{ t-count } \\
\hline & & $\mathrm{B}$ & Std. Error & & & & \\
\hline \multirow{4}{*}{1} & (Constant) & 4.345 & 2.978 & & 1.459 & .147 & \\
\hline & Internal Control System & .069 & .032 & .145 & 2.151 & .033 & 1.65462 \\
\hline & Human Resource Competence & .215 & .056 & .249 & 3.832 & .000 & 1.65462 \\
\hline & $\begin{array}{l}\text { Information Quality of Local Government } \\
\text { Financial Statement }\end{array}$ & .441 & .064 & .483 & 6.870 & .000 & 1.65462 \\
\hline
\end{tabular}

a. Dependent Variable: Financial Accountability

$\mathrm{H}_{1}$ : Internal control system has positive effect on the information quality of local government financial statement.

Based on Table 1 it appears that the value of $t$ count on the internal control system variable is 6.185 greater than the t table that has been obtained previously which is equal to $1.65455(6.185>1.65455)$ with the significance value is $0.000<0.05$, which means the internal control system partially has a significant positive effect on the quality of government financial statement information.

$\mathrm{H}_{2}$ : Human resource competence has positive effect on the information quality of local government financial statement.

Table 1 shows that the value of $t$ calculated on human resource competence variable of 5.089 is greater than the table $(5.089>1.65455)$ with the significance value is $0.000<0.05$, which means human resource competence partially has a significant positive effect on the information quality of local government financial statement.

$\mathrm{H}_{3}$ : Internal control system has positive effect on the financial accountability.

Based on Table 2 it is known that the value of $t$ count on the internal control system variable is 2.151 greater than the $t$ table that has been obtained previously which is equal to $1.65462(2.151>1.65462)$ with the significance value is $0.033<0.05$ which means the internal control system partially has a significant positive effect on financial accountability.

$\mathrm{H}_{4}$ : Human resource competence has positive effect on the financial accountability.

Table 2 shows that the calculated t value in the Human Resource Competence variable of 3.832 is greater than the t table $1.65462(3.832>1.65462)$ with the significance value is $0.000<0.05$ which means the competence of human resources partially has a significant positive effect on financial accountability.

$\mathrm{H}_{5}$ : Information quality of local government financial statement has positive effect on the financial accountability.

Based on Table 2, it appears that the calculated t value in the Information Quality of Local Government Financial Statement variable of 6.870 is greater than the t table $1.65462(6.870>1.65462)$ with the significance value is $0.000<0.05$ which means that Information Quality of Local Government Financial Statement partially has a significant positive effect on financial accountability.

\subsection{Path Analysis}

\section{Table 3}

Determination Coefficient Equation 1

\begin{tabular}{ccccc}
\hline Model & $\mathrm{R}$ & $\mathrm{R}$ Square & Adjusted R Square & Std. Error of the Estimate \\
\hline 1 & $.667^{\mathrm{a}}$ & .444 & .437 & 3.553 \\
\hline a. Predictors: (Constant), Human Resource Competence, Internal Control System & &
\end{tabular}

a. Predictors: (Constant), Human Resource Competence, Internal Control System 
Based on Table 3, to calculate the path coefficient the following formula is used:

$$
e 1=\sqrt{1-R^{2}}=\sqrt{1-0.444}=0.745654
$$

Meanwhile, structural equation 1 based on Table 1 and Table 3 above, can be known as follows:

$$
\mathrm{Y}=0.422 \mathrm{X}_{1}+\mathbf{0 . 3 4 7} \mathrm{X}_{2}+\mathbf{0 . 7 4 5 6 5 4} \mathrm{e}_{1}
$$

Table 4

Determination Coefficient Eq. (2)

\begin{tabular}{ccccc}
\hline Model & $\mathrm{R}$ & $\mathrm{R}$ Square & Adjusted R Square & Std. Error of the Estimate \\
\hline 1 & $.754^{\mathrm{a}}$ & .569 & .561 & 2.863 \\
\hline $\begin{array}{l}\text { a. Predictors: (Constant), Information Quality of Local Government Financial Statement, Human Resource Competence, Internal Control } \\
\text { System }\end{array}$
\end{tabular}

Based on Table 4, to calculate the path coefficient the following formula is used:

$e 2=\sqrt{1-R^{2}}=\sqrt{1-0.569}=0.656505$

Meanwhile, structural Eq. (2) based on Table 2 and Table 4 we have,

$$
Z=0.145 X_{1}+0.249 X_{2}+0.483 Y+0.656505 e_{2}
$$

The structural equation can be clarified by illustration with the path analysis structure model as follows.

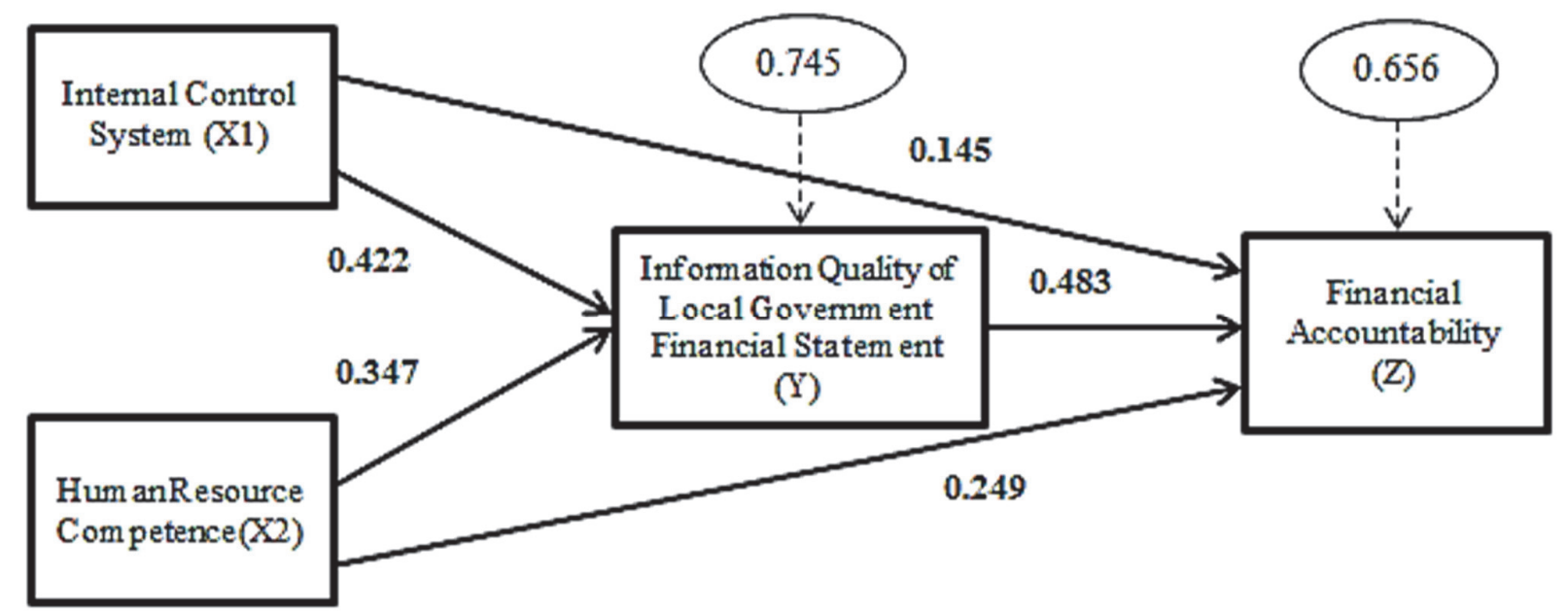

Fig. 1. The results of the testing different hypotheses

Then to find out the direct effect, indirect influence, and path coefficients of each variable that can be seen in the following table:

Table 5

Path Analysis Result of Eq. (1) and Eq. (2) for the Direct and Indirect Influence

\begin{tabular}{ccccc}
\hline Variable & Path & The Direct Influence & The Indirect Influence & Total \\
\hline $\mathrm{X}_{1}$ on $\mathrm{Y}$ & & 0.422 & & 0.422 \\
$\mathrm{X}_{2}$ on $\mathrm{Y}$ & & 0.347 & & 0.347 \\
$\mathrm{Y}$ on $\mathrm{Z}$ & & 0.483 & $0.422 \times 0.483=0.203826$ & 0.3483 \\
$\mathrm{X}_{1}$ on $\mathrm{Z}$ & & 0.145 & $0.347 \times 0.483=0.167601$ & 0.416601 \\
$\mathrm{X}_{2}$ on $\mathrm{Z}$ & & 0.249 & & 0.745654 \\
$\mathrm{e} 1$ & 0.745654 & & & 0.656505 \\
$\mathrm{e} 2$ & 0.656505 & & & \\
\hline
\end{tabular}

Based on Table 5 above, it can be described as follows: 
a. The internal control system $\left(\mathrm{X}_{1}\right)$ variable directly has a positive and significant effect on information quality of local government financial statement $(\mathrm{Y})$. The coefficient of direct influence is 0.422 and the significance is 0.000 . This means every enhancement in the Internal Control System will increase the information quality of local government financial statement by 0.422 or $42.2 \%$. The application of good and effective internal control system to the government of South Sumatra Indonesia, will tend to produce quality financial statement information that is capable of supporting the improvement of the information quality of financial statement. The results of this hypothesis testing empirically support the studies conducted by Modo et al. (2016) who conducted research on the SKPD of the Talaud Islands Regency government. This result is also in accordance with the results of research conducted by Nuryanto and Afiah (2013) who stated the higher application of internal control in local government, the higher the quality of financial statement. In general, this study supports Government Regulation No. 60 of 2008 which defines the Internal Control System as an integral process in actions and activities carried out continuously by the leadership and all employees to provide adequate confidence in achieving organizational goals through effective and efficient activities, reliability financial reporting, safeguarding state assets, and compliance with laws and regulations.

b. Variable of human resource competence $\left(\mathrm{X}_{2}\right)$ directly has a positive and significant effect on information quality of local government financial statement $(Y)$. The coefficient of direct influence is 0.347 and the significance is 0.000 . This means that human resource competence will increase the information quality of local government financial statement by 0.347 or by $34.7 \%$. The better the competency of the government employees of South Sumatra, the better the information quality of financial statements tend to be produced by the government of South Sumatra, Indonesia. This result is in line with the results of research conducted by Iskandar and Setiyawati (2015) who stated the internal accountant's competences have positive effects on the quality of financial reporting and research conducted by Anggriawan and Yudianto (2018) who agreed that human resources influence the information quality of West bandung District financial statements. On the contrary, this result is not in accordance with Mustafa et al. (2010) who found no influence between human resource capacity on reliability of financial reporting. This unsignificance is possible due to the condition of human resource capacity in the accounting / financial administration subdivision that has not been supported. In general, the results of this study support the theory of competence according to Hutapea and Thoha (2008) which states that competence-based human resources can improve capacity and build foundations, because if the people working within the organization have the right competence in accordance with the demands of their work, these people are able both in terms of knowledge, skills, and mental and productive character.

c. The internal control system $\left(\mathrm{X}_{1}\right)$ variable has a positive and significant effect on financial accountability $(Z)$ both directly and indirectly. The direct effect coefficient is 0.145 while the indirect effect is 0.203826 . This means that if the internal control system increases, the financial accountability will also increase. Both directly and mediated by information quality of local government financial statement. This suggests that a good of internal control system increases the information quality of local government financial statements, so that it impacts on the improved of financial accountability.

The results of this hypothesis testing empirically support the studies conducted by Kewo (2017) who found that the application of internal control influence on financial accountability of local governments in Indonesia. The better the implementation of internal control, the better the accountability of the local government.

d. The human resource competence $\left(\mathrm{X}_{2}\right)$ variable has a positive and significant effect on financial accountability $(Z)$ both directly and indirectly. The direct effect coefficient is 0.249 while the indirect effect is 0.167601 . This means that if human resource competence increases, the financial accountability will also increase. Both directly and mediated by information quality of local government financial statement. The result of this study is in accordance with research conducted by Santoso (2016) where human resource competency has a significant positive effect on regional 
financial accountability, this shows there is a positive influence between human resource competencies and regional financial accountability, thus increasing the competence of human resources will increase regional financial accountability.

e. Information quality of local government financial statement $(\mathrm{Y})$ variables directly have positive and significant effect on financial accountability $(Z)$. The coefficient of direct influence is 0.483 and the significance is 0.000 . This means that if the information quality of local government financial statements increases, the financial accountability will also increase. Every enhancement in information quality of local government financial statements will increase the financial accountability by 0.483 or $48.3 \%$. The results of this hypothesis testing empirically support the research conducted by Nurrizkiana et. al. (2017) where the presentation of regional financial statement has a positive and significant effect on the accountability of regional financial management. The result of this study is in accordance with research from Iskandar \& Setiyawati (2015) who found the quality of financial reporting have a positive effect on the financial accountability, even stronger effect and Indriasih and Koeswayo (2014) that the quality of financial reporting influence the performance accountability.

f. The most influential variable on information quality of local government financial statement (Y) is internal control system, while the most influential variable on financial accountability $(Z)$ is information quality of local government financial statement.

g. Based on Table 3, the Adjusted R Square value is obtained $=0.437=43.7 \%$. This means the magnitude of the influence of internal control system and human resource competence on information quality of local government financial statement is $43.7 \%$ and the rest is influenced by other variables not included in this study.

h. Based on Table 4, the Adjusted R Square value is obtained $=0.561=56.1 \%$. This means the magnitude of the influence of internal control system, human resource competence and information quality of local government financial statement toward financial accountability is $56.1 \%$ and the rest is influenced by other variables not included in this study.

\section{Conclusion and Implication}

Based on the research carried out on the Government of the Province of South Sumatra, Indonesia there are several issues which can be concluded. The results of this study are answers to what was stated and enquired in the research objectives, research questions and hypotheses about the effect of the internal control system and human resource competence on the information quality of local government financial statement and financial accountability in the Government of South Sumatra, Indonesia. First, internal control system and human resource competence have found to have a positive and significant effect on the information quality of local government financial statement on the Government of the Province of South Sumatra, Indonesia. Then, internal control system and human resource competence have shown to have a positive and significant effect on the financial accountability on the Government of the Province of South Sumatra, Indonesia, both directly and indirectly mediated by the information quality of local government financial statement. The findings of the study can develop existing accounting literature, and strengthen previous research that is related to the information quality of financial statement and the factors that influence. Moreover, the results of this study can also provide empirical evidence for academics and consideration for conducting further studies. Based on the perspective of practical implications, the results of this study can be beneficial to the government as input and material considerations in determining policies specifically related to improving the quality of information on government financial statements and financial accountability. Researchers have realized that there were still many weaknesses in this study due to some limitations. This research was only conducted in the South Sumatra Provincial Government, so that the results of this study could not be generalized to all objects. In addition, the variables tested on the model developed in this study were only 4 variables, namely internal control system, human resource competence, the information quality of local government financial statement and financial accountability. The problem of subjectivity from respondents can result in the results of this study being vulnerable to the bias of respondents' answers. The use of interview techniques for people 
who are competent in this case the OPD (agency) leadership can reduce the bias of respondent's answers. Also it is expected that further research can expand the research area in other regions and use more samples to make research more accurate.

\section{References}

Abi, S., Pituringsih, E., \& Husnan, L. H. (2018). Determinant of regional financial management accountability and its consequences to the stakeholder trust: A study at regional government in Dompu, Indonesia, 6(2), 230247.

Albattat, A. R. (2018). The leader punishment behavior, job satisfaction and organizational commitment of F \& B employees in 5-Star Hotels, (June 2017).

Anggriawan, F. T., \& Yudianto, I. (2018). Factors affecting information quality of local government financial statement of west Bandung District, West Java Province, Indonesia. Journal of Accounting Auditing and Business, 1(1), 34-46.

Apekshanirmali, K. A., Mohd Shukri, Ali Khatibi, \& Ferdous Azam, S. M. (2017). Internal branding-A conceptual review of related concepts. International Journal of Scientific and Research Publications, 7(8), 116-125.

Atmadja, A. T., \& Saputra, K. A. K. (2018). Determinant factors influencing the accountability of village financial management. Academy of Strategic Management Journal, 17(1), 1-9.

Audit Board of the Republic of Indonesia. (2018). Summary of Semester Examination Results (IHPS) I in 2018. Indeks Hasil Pemeriksaan Semester 1 Tahun 2018.

Bin Abdullah, A., \& Nor Izah Ku Ismail, K. (2008). Disclosure of voluntary accounting ratios by Malaysian listed companies. Journal of Financial Reporting and Accounting, 6(1), 1-20.

Dzomira, S. (2014). Internal controls and fraud schemes in Not-For-Profit organisations: A guide for good practice. Research Journal of Finance and Accounting, 5(2), 118-126.

Fung, B. (2014). The demand and need for transparency and disclosure in corporate governance. Universal Journal of Management, 2(2), 72-80.

Freeman, R. E. (1999). Divergent stakeholder theory. Academy of Management Review, 24(2), 233-236.

Grace, N. (2015). New public management and accrual accounting basis for transparency and new public management and accrual accounting basis for transparency and accountability in the Nigerian public sector, (September). https://doi.org/10.9790/487X-1673104113

Hafiz, A. (2017). Temuan BPK Soal Penyusunan APBD Provinsi Sumsel "Pemborosan Keuangn Dan Kurang Menyalurkan Bagi Hasil ke Daerah.” Retrieved September 2, 2018, from http://www.transformasinews.com

Halim, A., \& Abdullah, S. (2006). Hubungan dan Masalah Keagenan di Pemerintah Daerah. Jurnal Akuntansi Pemerintahan, 2(1), 53-64. https://doi.org/10.1017/CBO9781107415324.004

Hutapea, P., \& Thoha, N. (2008). Kompetensi Komunikasi Plus: Teori, Desai, Kasus, dan Penerapan untuk HR dan Organisasi yang dinamis, Jakarta. Gramedia Pustaka Utama.

Idris, A. L. M., Surasni, N. K., \& Irwan, M. (2018). The Determinant Disclosure of Internet Financial Reporting in District and City Government in Indonesia, (February), 62-74.

IFAC. (2012). Public Sector Financial Management Transparency And Accountability: The Use Of International Public Sector Context : Public Sector Financial Management, (March), 1-6.

IFAC. (2018). International Public Sector Financial Accountability 2018 Status Report.

Indriasih, D., \& Koeswayo, P. S. (2014). The effect of government apparatus competence and the effectiveness of government internal control toward the quality of financial reporting in local goverment. Research Journal of Finance and Accounting, 5(20), 38-47.

Isaiah, S. U., \& Ericsson, H. C. (2012). Human Resource Management and Organizational Achievement Case Study of the Lagos State Education District III.

Iskandar, D., \& Setiyawati, H. (2015). The effect of internal accountants' competence on the quality of financial reporting and the impact on the financial accountability. International Journal of Managerial Studies and Research, 3(5), 55-64.

Jensen, M. C., \& Meckling, W. H. (1976). Theory of the firm: Managerial behavior, agency costs and ownership structure. Journal of Financial Economics, 3(4), 305-360.

Karagül, A. A., \& Özdemİr, A. (2012). Evaluation of financial information quality attributes: A comparison from Turkey. International Journal of Business and Social Science., 3(23), 45-55.

Kasim, E. Y. (2015). Effect of government accountants competency and implementation of internal control to the quality of government financial reporting. International Journal of Business, Economics and Law, 8(1), $97-$ 105.

Kewo, C. L. (2017). The influence of internal control implementation and managerial performance on financial 
accountability local government in Indonesia. International Journal of Economics and Financial Issues, 7(1), 293-297.

Lembaga Administrasi Negara. (2000). Akuntabilitas dan Good Governance. Modul Sosialisasi Sistem Akuntabilitas Kinerja Instansi Pemerintah (AKIP).

Matuleviciene, M., \& Stravinskiene, J. (2015). The importance of stakeholders for corporate reputation. Engineering Economics, 26(1), 75-83.

Modo, S. M., Saerang, D. P. E., \& Poputra, A. T. (2016). Analisis Faktor-Faktor yangMempengaruhi Kualitas Informasi Laporan Keuangan Pemerintah Daerah, 14-30.

Mustafa, S., Sutrisno, \& Rosidi. (2010). Analisis Faktor - Faktor yang Berpengaruh terhadap Keterandalan dan Ketepatwaktuan Pelaporan Keuangan pada SKPD Pemerintah Daerah Kota Kendari. Jurnal Ekonomi Bisnis, 1(13), 73-84.

Nur, S. W. (2015). Pengaruh Penerapan Prinsip-Prinsip Akuntansi terhadap Kualitas Informasi Laporan Keuangan dengan Akuntabilitas Publik dan Sistem Pengendalian Intern sebagai Varibel Moderating pada Pemerintah Kabupaten Maros, 9, 31-44.

Nurlis. (2018). The effect of the government accounting standards implementation and apparatus competency on the quality of the local government financial reporting ( Case Study at Klaten District Gov. ), 9(8), 63-69.

Nurlis, \& Yadiati, W. (2017). The Influence of Internal Control Effectiveness , Information Technology Utilization and Human Resources Competence on Local Government Financial Reporting Quality ( Survey on SKPD Banten Provincial Government and Serang City ), 8(12), 111-124.

Nurmayanti. (2017). Akuntabilitas Pemda Masih Buruk, Negara Boros Rp 400 Triliun. Retrieved August 25, 2018, from https://www.liputan6.com

Nurrizkiana, B., Handayani, L., \& Widiastuty, E. (2017). Determinan Transparansi dan Akuntabilitas Pengelolaan Keuangan Daerah dan Implikasinya Terhadap Kepercayaan Public-Stakeholders. Jurnal Akuntansi Dan Investasi, 18(1), 28-47. https://doi.org/10.18196/jai.18159

Nuryanto, M., \& Afiah, N. N. (2013). The impact of apparatus competence, information technology utilization and internal control on financial statement quality (Study on Local Government of Jakarta Province -Indonesia). World Review of Business Research Issue. Pp, 3(4), 157-171.

Perera, D., Khatibi, A., \& Chinna, K. (2013). Gap Analysis of Employee-Organization Congruence Factors: Perspective of Gap Analysis of Employee-Organization Congruence Factors: Perspective of Factory employees in Sri Lankan Apparel Sector, (May 2016).

Rahman, N., Othman, M., Yajid, M., Rahman, S., Yaakob, A., Masri, R., Ramli, S \& Ibrahim, Z. (2018). Impact of strategic leadership on organizational performance, strategic orientation and operational strategy. Management Science Letters , 8(12), 1387-1398.

Ramdhani, D., Fadli, A., Virgina, C., \& Pohan, E. (2016). the Organization, Accountability and Performance of Public Organization. Proceeding: The 2 Nd International Conference on Business Management (ICBM 2016), 1(3), 118-133.

Sagara, Y. (2015). The effect of implementation accounting information system and competence of human resources on the quality of financial reporting, 6(10), 111-116.

Santoso, E. B. (2016). Pengaruh Sistem Pengendalian Intern Pemerintah, Pemanfaatan Teknologi Informasi dan Kompetensi Sumber Daya Manusia terhadap Akuntabilitas Keuangan Daerah. Lampung University.

Sieger, P., Zellweger, T., \& Aquino, K. (2013). Turning agents into psychological principals: Aligning interests of non-owners through psychological ownership. Journal of Management Studies, 50(3), 361-388.

Sudiarianti, N. M., Ulupui, I. G. K. A., \& Budiasih, I. G. A. (2015). Pengaruh Kompetensi Sumber Daya Manusia Pada Penerapan Sistem Pengendalian Intern Pemerintah Dan Standar Akuntansi Pemerintah Serta Impikasinya Pada Kualitas Laporan Keuangan Pemerintah Daerah. Jurnal Bisnis Dan Manajemen, 4(1), 1-25.

Tarofder, A. K., Azam, S. F., \& Jalal, A. N. (2017). Operational or strategic benefits: Empirical investigation of internet adoption in supply chain management. Management Research Review, 40(1), 2852.

Thomas, I., \& Nadiyasu, J. B. (2017). Public Sector Financial Management Reform ( PSFMR ) and International Accounting Standards ( IPSASs ), 8(12), 125-132.

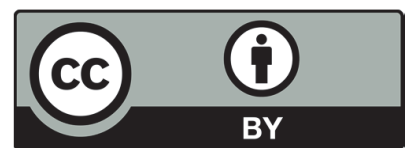

(C) 2019 by the authors; licensee Growing Science, Canada. This is an open access article distributed under the terms and conditions of the Creative Commons Attribution (CCBY) license (http://creativecommons.org/licenses/by/4.0/). 